\title{
RINTISAN PERADABAN PROFETIK UMAT MANUSIA MELALUI PERISTIWA TURUNNYA ADAM AS KE-DUNIA
}

\author{
SAIHU \\ Institut PTIQ Jakarta \\ madesaihu@ptiq.ac.id
}

\begin{abstract}
Abstrak
Tulisan ini membahas tentang sejarah peristiwa turunnya Nabi Adam AS ke dunia yang disinyalir sebagai rintisan profetik peradaban umat manusia. Tulisan berfokus menelusuri sebab-musabab turunnya Nabi Adam AS, apakah turunnya Nabi Adam AS disebabkan oleh kesalahan yang dilakukannya yaitu memakan buah khuldi, ataukah memang kehendak Tuhan dia diturunkan ke bumi sekalipun dengan tanpa melakukan kesalahan. Sumber data diperoleh melalui observasi di beberapa buku dan ayat serta tafsir al-Qur'an yang terkait dengan tema yang dibahas. Dalam menganalisa tema yang dibahas, tulisan ini menggunakan beberapa pemikiran mufasir, antara lain al-Thabari (838-923 M), al-Qurtubi (1214-1273 M), dan M. Quraish Shihab. Tulisan memperlihatkan bahwa kisah Nabi Adam AS adalah siklus kehidupan dalam sejarah peradaban manusia sampai akhir zaman. Manusia mesti berkaca pada kisah kehidupan Adam, bahwa kemuliaan manusia terdapat pada pengetahuan dan ketaatannya pada perintah Tuhan. Sementara kejatuhan manusia adalah ketika melupakan ajaran-ajaran Tuhan dan rendahnya moralitasnya. Sebagaimana yang disebut oleh Ibnu Khaldun, setiap peradaban memiliki pola dan siklus yang sama, yaitu; merintis, membangun, kemunduran, kehancuran.
\end{abstract}

Kata Kunci: Adam, Profetik, Rintisan, Kemuliaan, Kejatuhan

\begin{abstract}
This paper discusses the history of the fall of the Prophet Adam AS to the world which was allegedly a prophetic pioneering of human civilization. The writing focuses on tracing the causes of the decline of the Prophet Adam, whether the decline of the Prophet Adam was caused by a mistake he made, namely eating khuldi fruit, or indeed God's will he was sent down to earth even without making mistakes. Sources of data obtained through observation in several books and verses as well as the interpretation of the Qur'an related to the themes discussed. In analyzing the themes discussed, this paper uses several commentators' thoughts, including al-Tabari (838-923 M), al-Qurtubi (1214-1273 M), and M. Quraish Shihab. The writings show that the story of the Prophet Adam AS is a cycle of life in the history of human civilization until the end of time. Humans must reflect on the life story of Adam, that human glory lies in knowledge and obedience to God's commands. While the fall of man is when he forgets the teachings of God and low morality. As mentioned by Ibn Khaldun, every civilization has the same pattern and cycle, namely; pioneering, building, setbacks, destruction.
\end{abstract}

Keywords: Adam, Prophetic, Stub, Glory, Fall 


\section{PENDHULUAN}

Manusia sering diperdebatkan manusia sendiri, karena manusia kebanyakan tidak mengetahui fitrah keberadaannya sendiri. ${ }^{1}$ Demikianlah sejarah manusia pertama, memang masih dalam kondisi yang debatable,dalam kajian antropologi keberadaannya tidak dapat dijelaskan. Sejauh ini, belum ada satu penelitian empiris yang mengatakan bahwa Adam itu benar-benar ada sebagai realitas. Dikalangan para pemikir yang menganut paham evolusi, menyatakan bahwa manusia adalah produk alam dan muncul dengan sendirinya berdasarkan hasil seleksi alam. Bahkan Matt Ridley menyebutkan, bahwa sepuluh juta tahun yang lalu, sekurangnya hidup dua spesies ungka di Afrika, salah satu dari keduanya adalah leluhur manusia. ${ }^{2}$ Berbeda dengan Pidley, Jared Diamond dalam bukunya berjudul "Guns, Germs, dan Steel" menyebutkan bahwa antara manusia (Homo Sapiens) berbeda sama sekali dengan Australopitechus africanicus, Homo habilis, dan Homo erektus jika dilihat dari ukuran otak. Hal demikian dapat terlacak dari fosil-fosilnya. ${ }^{3}$ Perdebatan-perdebatan seputar manusia (Adam) tidak ada habisnya. Apalagi jika didekati dengan kajian filsafat.

Akan tetapi setidaknya cerita tentang Adam dapat dilacak dalam sumber-sumber agama. Adam diyakini oleh tiga agama besar; Yahudi, Kristen, dan Islam sebagai manusia pertama di dunia ini. Riwayat Adam tertulis baik pada kitab perjanjian lama (Kitab Kejadian) maupun dalam Al-Qur'an. Umumnya teks-teks agama tersebut menceritakan Adam sejak penciptaannya, kehidupan di surga, hingga terjerumusnya Adam oleh godaan Iblis. Adapun cerita tentang Adam dan Anak keturunannya sangat sedikit sekali.

Dengan referensi yang sangat terbatas penulis akan membahas posisi Adam sebagai manusia pertama dan seorang Nabi pembawa ajaran Allah, bahkan disebut dengan khalifah di muka Bumi (QS. Al-Baqarah [2]: 30). Adapun perdebatan-perdebatan tentang Nabi Adam merupakan hasil evolusi atau hasil ciptaan Allah tidak menjadi titik fokus pembahasan. Karena keduanya sama memiliki kelemahan, teori penciptaan hanya berdasarkan teks-teks agama, sementara teori evolusi tidak dapat membuktikan secara rinci.

\section{TINJAUAN PUSTAKA}

Sebagaimana disampaikan di atas bahwa tiga agama semit mengakui keberadaan Adam sebagai sosok manusia pertama yang melahirkan peradaban manusia di muka Bumi. Dalam perjanjian lama (kejadian 2: 1-25) yang bila diringkas: bermula dari penciptaan langit dan bumu dan segala isinya. Pada hari ketujuh Allah menyelesaikan pekerjaan yang dibuatnya dan memberkatinya, tetapi belum ada tumbuhan apapun, sebab hujan belum orang diturunkan ke bumi dan belum ada orang untuk mengelola tanah. Lalu ada kabut dari bumi naik ke atas dan membasahi seluruh permukaan bumi. Ketika itu Tuhan Allah membentuk manusia dari debu tanah dan menghembuskan nafas hidup ke dalam hidungnya dan manusia menjadi mahluk hidup. Selanjutnya Tuhan Allah membuat taman di Eden. Lalu Tuhan Allah menumbuhkan pohon-pohon yang menarik dan baik dimakan buahnya. Semua buah dari pohon itu boleh dimakan kecualin pohon pengetahuan tentang baik dan buruk. Karena, jika dimakan buah pohon tersebut mereka akan "mati". 4

Dalam Al-Qur'an Nabi Adam disebutkan dalam banyak ayat, antara lain: QS. AlBaqarah [2]: 30-39, QS. Ali-Imran [3]: 33-34 dan 59-60, QS. Al-A'raf [7]: 11-25 dan 172, QS. Al-Isra [17]: 61, QS. Al-Kahfi [18]: 50, QS. Maryam [19]: 58, QS. Thaha [20]: 115-123, dan QS. Shad [38]: 71-85. Dengan banyaknya ayat terkait dengan Adam ini dapat membantu

\footnotetext{
${ }^{1}$ Muflih Abdullah \& Dedi Supriyadi, Filsafat Sejarah (Bandung: Pustaka Setia, 2012), 78.

2 Matt Pidley, Genom; Kisah Spesies Manusia Dalam 23 Bab (Jakarta: Gramedia Pustaka Utama, 2005), 24

${ }^{3}$ Jared Diamond, Guns, Germs, Dan Steel (Jakarta: kpg, 2013), 31-34.

4 Ali Audah, Nama Dan Kata Dalam Al-Qur'an: Pembahasan Dan Perbandingan (Jakarta: Pustaka Litera Antar Nusa, 2011), 27-30.
} 
kita untuk merekonstruksi kebudayaan Nabi Adam dan keturunannya. Dari segi penciptaan, kehidupan surga, dan proses kejatuhannya antara Bibel, Tradisi Yudeo-Kristen, dan Islam tidak banyak perbedaan, kecuali pada perinciannya. Bibel melibatkan ular dalam proses menyusupnya Iblis ke dalam surga, sementara Al-Qur'an tidak ada penjelasan apapun.

Akan tetapi alur cerita yang sangat menonjol dari Al-Qur'an tentang penciptaan Adam, yaitu; protes Malaikat kepada Allah sebagaimana yang terdapat dalam QS. Al-Baqarah [2]: 30. Keberatan para Malaikat didasarkan pada alasan bahwa mahluk manusia ini nantinya justru akan membuat kerusakan di muka bumi dan menumpahkan darah. Namun, Allah menepisnya dengan berkata; "Sungguh, Aku lebih mengetahui dari apa yang kamu tidak ketahui". Dari penggalan kisah tersebut, dapat diartikan bahwa dalam kesejarahannya, Adam sangat kontroversial. Mulai dari penciptaannya, bahkan surganya pun masih menyimpan tanda tanya. Nurcholish Madjid mempertanyakan tentang surga yang ditempati oleh Adam dan pasangannya dengan mengajukan pertanyaan; jika surga yang ditempati Adam dan Istrinya sama dengan surga yang dijanjikan dengan kaum beriman, kenapa ada pembangkangan disana? Tidak hanya pembangkangan terjadi, justru setan pun masuk disana, padahal dalam Al-Qur'an digambarkan bahwa syurga kelak tidak ada lagi pembicaraan sia-sia atau kotor, apalagi pembangkangan kepada Allah. Yang ada ialah kedamaian sempurna dan abadi (QS. Al-Waqi'ah [56]: 25-26). ${ }^{5}$

Selanjutnya makna profetik bisa ditarik ke dalam bahasa Arab النبوية maksudnya adalah segala sesuatu yang bersumber dari Nabi, baik secara perkataan, perbuatan, dan pengakuan yang khususnya. Profetik berasal dari bahasa Yunani prophetes sebuah kata benda yang menyebut orang berbicara awal atau orang yang memproklamirkan diri dan berarti juga orang yang berbicara masa depan. ${ }^{6}$ Menurut Shofan, nilai profetik merupakan seperangkat teori yang tidak hanya mendeskripsikan dan mentransformasikan gejala-gejala, dan tidak hanya sekedar mengubah sesuatu hal hanya karena stigma perubahan, akan tetapi lebih dari itu, mengarahkan suatu perubahan atas dasar cita-cita etik dan profetik. ${ }^{7}$

Cikal bakal dari diskursus profetik adalah kajian filsafat, yaitu filsafat profetik. Pemikiran filosofisnya didasarkan pada nilai-nilai kenabian dalam Al-Qur'an dan As-Sunnah dengan berbagai upaya pemikiran reflektif-spekulatif sampai pada penelitian empirik sehingga menemukan kebenaran normatif dan faktual aplikatif yang memiliki daya sebagai penggerak umat sehingga terbentuk khairu ummah atau komunitas ideal. Secara historis, filsafat profetik diperbincangkan secara intensif oleh Ibnu Arabi (1165-1241) dan Suhrawardi (1155-1191) yang secara garis besar mengkritik filsafat dan Yunani serta menawarkan filsafat propetik yang intinya adalah dialektika manusia, alam, dan Tuhan dikembangkan untuk mendapat produk pemikiran baru sebagai alternatif pemikiran Barat yang dinyatakan gagal. Dalam perkembangannya, pemikiran tersebut di atas dengan beberapa teori yang diadopsi oleh Muhammad Iqbal. Iqbal ini dikenal sebagai seorang filosof dari benua India yang dikategorikan sebagai penggerak tasawuf falsafah pada abad 20 yang dipadukan dengan tasawuf cinta. Kemudian diulas pula oleh Roger Garaudy seorang guru besar filsafat Universitas politiers di Perancis. Dalam kesimpulannya Roger Garaudy menyatakan bahwa filsafat Barat dari Yunani sampai modern mengekang diri pada kajian manusia dan alam, tidak sampai merasakan hubungannya dengan Tuhan. Berbeda dengan filsafat Islam, yang menuurut Al-Qur'an dapat mengantarkan manusia pada alam ketuhanan dan kenabian.

Al-Qur'an menggunakan Istilah nabi dan rasul untuk menyebut utusan Allah bagi manusia. Dalam Al-Qur'an kata nabi bermakna "pembawa kabar", dia datang dari Allah

\footnotetext{
${ }^{5}$ Budhy Munawar-Rachman, Ensiklopedi Nurcholis Madjid (Jakarta: Paramadina, 2011), 19-20.

6 Miftahulloh, Pendidikan Profetik Perspektif Moh. Roqib Dan Implikasi Dalam Rekonstruksi Pendidikan Islam Integratif (Purwokerto: IAIN Purwokerto, 2017), 25.

${ }^{7}$ Moh. Shofan, Pendidikan Paradigma Profetik; Upaya Konstruktif Membongkar Dikotomi Sistem Pendidikan Islam (Yogyakarta: IRCiSoD, 2004), 31.

270 | Mumtäz Vol. 3 No. 1, Tahun 2019
} 
untuk member peringatan atas perbuatan buruk dan memberi kabar gembira atas perbuatan baik. karena itu, istilah mubasysyirin (pemberi kabar gembira) dan mundzirin (pemberi peringatan) sering muncul dalam Al-Qur'an. Dalam Al-Qur'an, kata nabi dalam bentuk tunggal terulang sebanyak 54 kali. Jamaknya dengan pola jam' taksir, ambiya"disebut 5 kali, dan dengan pola jam' muzakkar salim, nabiyyun/nabiyyin, disebut sebanyak 16 kali.berdasarkan asal kata dan pengertian yang pertama, nabi berarti orang yang memiliki berita, sedangkan menurut asal kata dan pengertian kedua, nabi berarti orang yang memiliki derajat dan kedudukan yang tinggi. Tanpa mengabaikan kemungkinan dua asal kata dari kata nabi ini, Raghib al-Asfahani lebih cenderung memilih asal kata dan makna kedua, menurutnya tidak semua orang yang mendapat berita itu mendapatkan derajat yang tinggi. Sementara Abdul Halim Mahmud mantan Grand Syaikh Al-Azhar lebih condong kepada asal kata dan makna pertama, sebab semua orang yang diberitakan informasi lewat wahyu dapat dipastikan memiliki derajat yang tinggi. ${ }^{8}$ Fazlurrahman, memberikan pengertian yang berbeda antara nabi dan rasul. Nabi bermakna berarti seorang utusan Allah tanpa diberi hukum syari'at dan mungkin tanpa kitab suci, sedangkan rasul bermakna seorang utusan seorang utusan Allah yang diberikan hukum syari' at dan kitab suci. ${ }^{9}$

Lanjut Fazlurrahman, Meskipun distingsi tajam ini agak meragukan, karena Al-Qur'an menyebut beberapa tokoh agama sebagai nabi dan sekaligus sebagai rasul (Misalnya, QS. AlA'raf [7]: 158; QS. Maryam [19]: 51, 54), tetapi distingsi seperti ini memang disebutkan dalam Al-Qur'an. Menurut Fazlurrahman, frekuensi penggunaan kata nabi meningkat sejak periode akhir Makkah hingga periode Madinah. Secara umum, rasul mengemban peran yang lebih berat dari nabi, karena nabi bisa jadi pembantu bagi seorang rasul, misalnya Harun bagi Musa (QS. Maryam [19]: 51,53), meskipun para rasul dan nabi bisa bertugas bersama (QS. Yaasiin: 13, 16). Meskipun kenabian bersifat tidak terbagi-bagi, tetapi tidak semua nabi memiliki derajat yang sama (QS. Al-Baqarah [2]: 253; QS. Al-Isra' [17]: 55).

Jika Fazlurrahman membedakan antara nabi dan rasul, maka berbeda dengan Harun Nasution dalam buku "Filsafat dan Mistisme dalam Islam". Harun Nasution dengan menyandarkan pada teori Al-Farabi, memetakan antara nabi dan filosof. Filosof dapat mengetahui hakikat-hakikat sesuatu dengan akal ke sepuluh atau akal mustafad dan atas usahanya sendiri yaitu latihan dan kontemplasi. Sementara Nabi dapat mengetahui hakikathakikat melalui wahyu langsung dari Tuhan, tanpa melalui usaha. ${ }^{10}$ Sementara Mirza Tahir Ahmad, menyebutkan bahwa antara nabi dan filosof tidak memiliki perbedaan, mereka samasama sampai pada kebenaran yang hakiki. Dengan demikian Mirza menyebut Socrates sebagai nabi. ${ }^{11}$

\section{PEMBAHASAN}

\section{Membaca Sejarah Nabi Adam.}

Manusia pada dasarnya adalah mahluk yang gelisah, dari kegelisahannya tersebut sehingga timbul banyak ragam pertanyaan. Secara filologis, manusia itu sebangsa hewan biasa yang lemah, tidak memiliki pertahanan diri, tidak memiliki peralatan organis yang istimewa semacam belali pada gajah atau ekor berbisa pada kalajengking. Oleh sebab itu, Blaise Pascal (1623-1662) mengatakan bahwa alangkah berbahayanya apabila manusia menunjukkan dirinya sebagai sekadar mahluk yang memiliki sifat-sifat binatang, tanpa

${ }^{8}$ Kemenag, Tafsir Tematik Al-Qur'an; Kenabian Dalam Al-Qur'an (Jakarta: Lajnah Pentashih AlQur'an, 2012), 4.

${ }^{9}$ Fazlurrahman, Tema-Tema Pokok Dalam Al-Qur'an (Bandung: Mizan, 2017), 120.

${ }^{10}$ Harun Nasution, Filsafat Dan Mistisme Islam (Jakarta: Bulan Bintang, 2010), 20.

11 Mirza Tahir Ahmad, Wahyu; Rasionalitas Pengetahuan Dan Kebenaran (Jakarta: Naratja Press, 2014), 91-92. 
menunjukkan kebesarannya sebagai manusia. ${ }^{12}$ Manusia harus diarahkan pada suatu pencapaian yang tertinggi, sebagai manusia unggul.

Menurut Zainal Abidin, Manusia unggul tidak dilahirkan oleh alam atau proses genetik. Manusia unggul dapat terbentuk dengan ujian perbaikan kecerdasan dan pendidikan yang meningkatkan derajat serta keagungannya. ${ }^{13}$ Lanjutnya, energi, intelek, kehormatan atau kebanggaan diri, semuanya dapat menjadikan manusia unggul. Namun, kesemuanya itu harus selaras, gairah-gairah akan menjadi kekuatan, hanya jika mereka dipilih dan dipadukan oleh suatu tujuan besar, yang mampu membentuk berbagai keinginan yang masih kabur ke dalam kekuatan satu kepribadian. ${ }^{14}$ Apabila sifat alam adalah kesinambungan, ketertiban, dan kelangsungan tanpa perubahan, alam semangat sajalah yang mampu mencipta dan mengubah ke arah kesempurnaan. Semangat ini adalah karunia intelektual atas individu-individu. ${ }^{15} \mathrm{Jika}$ ditarik kepada sejarah individu bernama Adam, maka kesejarahannya merupakan proses aktualisasi diri dan penyingkapan kontribusi-kontribusinya terhadap pembentukan peradaban umat manusia.

Al-Qur'an, dengan cara yang sederhana dan penuh daya menekankan individualitas dan keunikan manusia. sebagai konsekuensinya adalah manusia mustahil menanggung beban atas perbuatan orang lain dan berhak atas hasil kerjanya sendiri. Menurut Iqbal, ada tiga hal yang jelas terpapar dalam Al-Qur'an; pertama, bahwa manusia adalah pilihan Tuhan (nabi) (QS. Thaha [20]: 122). Kedua, manusia dengan segala kekurangannya, dimaksudkan menjadi wakil Tuhan (QS. Al-Baqarah [2]: 30). Ketiga, bahwa manusia merupakan pengemban kepribadian bebas atas resiko sendiri (QS. Al-Ahzab [33]: 72). ${ }^{16}$

\section{Manusia sebagai 'Khalifah'}

Dalam QS. Al-baqarah [2]: 30 terdapat sebuah fenomena yang mengesankan bahwa Adam adalah mahluk kontroversial. Dan, menimbulkan perdebatan yang luar biasa antara Allah dan Malaikat. Sehingga pada ujung ayatnya, Allah harus mendikte Malaikat dengan keras, bahwa Allah lebih mengetahui segala sesuatu dibanding malaikat. Banyak penafsian terkait dengan fenomena berdebatan tersebut. salah satunya adalah bagaimana Malaikat mengetahui bahwa manusia (Adam) akan menumpahkan darah di muka bumi?

Menurut Allamah Kamal Faqih Imani, para malaikat mengetahui perkara yang diperdebatkan (bahwa manusia akan berbuat kerusakan) ini dari kata fil 'ardh (di muka bumi). Mereka mafhum bahwa manusia akan diciptakan dari tanah; dan karena kepelikan unsur tanah ini, maka secara alami akan menjadi sumber konflik dan kesulitan. Sebab, dunia yang mengandung unsur ini tidak dapat memenuhi sifat manusia yang tamak. Menurutnya, bahkan sekiranya seluruh dunia diberikan kepada seseorang, maka seseorang tersebut tetap tidak akan terpuaskan. Keadaan ini terkadang dapat menjadi sumber utama kejahatan dan pertumpahan darah khususnya ketika tidak ada cukup rasa tanggungjawab. ${ }^{17}$

Sebagian mufassir lainnya percaya, ramalan para malaikat akibat dari suatu fakta bahwa Adam bukanlah mahluk pertama di muka bumi, melainkan sebelumnya telah ada beberapa mahluk lainnya yang tingal di bumi dan melakukan kerusakan dan pertumpahan darah. Perbuatan buruk ini yang menyebabkan kecurigaan para malaikat menyangkut Adam dan keturunannya. Tafsiran ini sejalan dengan makna kata 'khalifah' yang berarti menggantikan (QS. Yunus [10]: 14). Menurut Abu Ja'far, bahwa kata khalifah adalah

${ }^{12}$ Supriyadi, Filsafat Sejarah, 78.

13 Zainal Abidin, Filsafat Manusia; Memahami Manusia Melalui Filsafat, (Bandung: Remaja Rosdakarya, 2014), Hal. 114. (Bandung: Remaja Rosdakarya, 2014), 114.

${ }^{14}$ Abidin, 115.

${ }^{15}$ Supriyadi, Filsafat Sejarah, 35.

${ }^{16}$ Iqbal, Rekonstruksi Pemikiran Religius Dalam Islam (Bandung: Mizan, 2016), 115-16.

${ }^{17}$ Allamah Kamal Faqih Imani, Tafsir Nurul Qur'an (Jakarta: Al-Huda, 2003), 159. 
mengganti mahluk sebelumnya. ${ }^{18}$ Dalam tafsir Al-Qurthubi kata khalifah juga dimaknai pengganti mahluk sebelumnya. Namun, Al-Qurthubi menjelaskan bahwa kata khalifah juga bisa dibaca khaliqah yang ditakwil sebagai Adam. Lebih lanjut, Al-Qurthubi mengatakan bahwa Adam adalah salah seorang utusan Allah yang menjalankan semua hukum dan perintah Allah. ${ }^{19}$ Demikian juga, tafsiran Syaikh Muhammad Ali Ash-Shabuni, khalifah adalah penganti dan sekaligus yang menjalankan perintah-perintah Allah. ${ }^{20}$ Sementara Hamka, memberikan penafsiran yang bercorak kontemporer, dengan kecerdasannya membangun sebuah persepsi bahwa, jika mahluk ini telah mencapai populasi yang banyak, mereka akan berebut kepentinan antara satu sama lain. Kepentingan antara individu dan golongan bertumbuk dengan individu dan golongan yang lain, maka beradulah yang keras timbullah pertentangan dan dengan demikian timbullah kerusakan dan bahkan akan timbul pertumpahan darah. $^{21}$

Berita malaikat mengalami kekeliruan, mereka mengira semua manusia itu sama dalam mengelola potensinya, dan mengangap bahwa manusia adalah satu corak dan warna dalam berpikir dan berperilaku. Seandainya, mereka mengalami dan menyaksikan proses historis mahluk sebelum Adam yang saling menumpahkan darah, maka malaikat terlalu menjeneralisir keadaan. Mereka tidak mengetahui bahwa dalam benih Adam akan ada banyak nabi besar seperti Muhammad Saw, Ibrahin As, Nuh As, Musa As, Isa As dan selain itu banyak lagi mukmin sejati yang rela mengorbankan harta dan kekayaan di jalan Allah. Dan akan muncul anak cucu Adam yang mana satu jam perenungannya sama dengan bertahuntahun ibadahnya para malaikat. ${ }^{22}$ Artinya manusia dengan kecerdasan yang Allah berikan mereka mampu membedakan yang benar dan salah, serta mampu mengontrol diri dan emosi mereka. Jika demikian, kekhalifahan mengharuskan mahluk yang diserahi tugas itu melaksanakan tugasnya sesuai petunjuk Allah yang memberikan tugas dan wewenang. Kebijaksaan yang tidak sesuai dengan kehendak-Nya adalah pelanggaran terhadap makna dan tugas kekhalifahan. ${ }^{23}$ Sebagai khalifah manusia tidak bebas untuk bertindak dengan sebebasbebasnya, melainkan mesti mengacu pada panduan dari Sang Maha Pencipta yang menghadirkannya di bumi (QS. Fatir [35]: 39).

Sebagai seorang khalifah, Allah mengajarkan Adam nama-nama benda seluruhnya, yaitu memberinya potensi pengetahuan tentang nama-nama atau kata-kata yang digunakan untuk menunjuk benda-benda, atau mengajarkannya mengenal fungsi benda-benda (QS. AlBaqarah [2]: 31-32). Setelah pengajaran Allah dicerna dengan baik oleh Adam, maka Adam diberikan keleluasaan untuk mendemontrasikan kemampuannya. Menurut Quraish Shihab, perintah tersebut bukan bertujuan menjawab pertanyaan malaikat, tetapi justru memberikan bukti bahwa anggapan mereka terhadap Adam adalah keliru. ${ }^{24}$ Pembekalan pengetahuan atau potensi ini sangat penting untuk Adam sebagai seorang khalifah yang bertugas membina dirinya, umatnya, dan alam semesta. Sebagai khalifah Allah di muka bumi, Adam bertugas memimpin sesama umat manusia dengan adil dan tidak mengikuti hawa nafsu; menegakkan hukum Allah dan menciptakan kemaslahatan bagi umat manusia. Pengetahuan ini juga penting untuk Adam sebagai seorang nabi dalam menjalankan tugas profetiknya, sebagai rahmat bagi manusia dengan tugas menyampaikan pesan-pesan Allah berupa agama sebagai

${ }^{18}$ Abu Ja'far Muhammad bin Jarir Ath-Thabari, Tafsir Ath-Thabari (Jakarta: Pustaka Azzam, 2007), 522.

${ }^{19}$ Al-Qurthubi, Tafsir Al-Qurthubi (Jakarta: Pustaka Azzam, 2007), 588.

${ }^{20}$ Muhammad Ali Ash-Shabuni, Shafwatut Tafasir (Jakarta: Pustaka Al-Kautsar, 2011), 63.

${ }^{21}$ Hamka, Tafsir Al-Azhar (Jakarta: Citra Serumpun Padi, 2005), 201.

${ }^{22}$ Imani, Tafsir Nurul Qur'an, 160.

${ }^{23}$ M. Quraish Shihab, Tafsir Al-Misbah; Pesan, Kesan, Dan Keserasian Al-Qur'an (Jakarta: Lentera Hati, 2002), 173.

${ }^{24}$ Shihab, 117. 
tuntunan kehidupan di dunia dan untuk meraih kebahagiaan dunia dan akhirat, menyeru manusia menuju jalan hidup yang benar, membacakan firman-firman Tuhan, mengajari manusia menyucikan jiwa, menjadi penerang kehidupan serta membawa berita gembira dan peringatan ancaman di akhirat.

\section{Adam Versus Iblis}

Dalam QS. Al-Baqarah [2]: 34 disebutkan bahwa Allah memerintahkan kepada para malaikat dan Azazil (sekarang menjadi Iblis) untuk sujud kepada Adam, maka maka para malaikat bersujud kepada Adam, kecuali Iblis. Mereka menolak untuk sujud karena mereka menganggap diri mereka lebih baik dari Adam. Adam terbuat dari tanah, sementara Iblis terbuat dari api (QS. Al-A'raf [7]: 12). Dan, pada akhirnya Iblis terusir keluar dari surga. Kemudian Iblis meminta agar golongannya hidup sampai hari kiamat, dan mempengaruhi anak Adam agar terjatuh pada keburukan dan kegelapan.

Dalam pertarungan ini, manusia (Adam) selalu berposisi defensif, sementara Iblis berposisi ofensif. Melihat kenyataan inilah Allah memberikan pembekalan terhadap Adam berupa potensi atau ilmu pengetahuan. Ilmu dan pengetahuan menjadi bekal untuk manusia mempertahankan diri agar tidak terjebak pada kehinaan dan kejatuhan moral dan spiritual. Menurut Muhammad Yunus, bahwa Iblis selalu memanfaatkan adanya masalah atau gap antara pengetahuan dan pengalaman empiris manusia dengan suatu iming-iming, kemewahan dan kekekalan. ${ }^{25}$ Dalam proses kejatuhan Adam dari surga yang disebabkan oleh setan, disebakan karena hilangnya keseimbangan diri. Menurut Ali Syari'ati, sebagaimana dikutip Suwito NS, bahwa kejatuhan Adam adalah suatu contoh kemungkinan bahwa manusia bisa saja mengalami kemelorotan derajat eksistensialnya, dari mulia ke kehinaan. ${ }^{26}$ Dalam AlQur'an dijelaskan bahwa manusia berulang-ulang diangkat derajatnya, berulang-ulang pula direndahkan. Mereka dinobatkan jauh mengungguli alam surga, bumi, dan bahkan para malaikat, akan tetapi pada saat yang sama mereka bisa tidak lebih berarti dibandingkan binatang sekalipun. ${ }^{27}$ Dengan demikian manusia mesti memiliki pengetahuan yang tinggi tentang dirinya sendiri. Jika dikaitkan dengan tugas profetik Adam dan para nabi yang lain adalah meloloskan manusia dari jebakan nafsu dan Iblis. Muhammad Yunus memahami kejatuhan Adam sebagai proses pembelajaran terhadap manusia bahwa kekekalan hanya milik Allah dan manusia harus menjalani proses pencarian jati diri, yaitu memahami proses awal penciptaan dan akhir kehidupan kembali kepada Allah. Bagi seluruh umat manusia, perlu menyadari bahwa dalam proses untuk mencari jati diri mereka memiliki kewajiban yang mendasar yaitu proses transformasi pengetahuan diri sampai pada puncak makrifatullah. ${ }^{28}$

Menurut Suwito NS, sebagai gabungan dari tanah yang rendah dan spirit yang suci, akhirnya manusia menjadi mahluk yang dua dimensi. Manusia mempunyai dua arah dan kecenderungan, yaitu yang satu membawa ke dasar paling bawah (kepada stagnansi sedimenter) atau ke dasar bawah hakikat yang paling rendah. Konsekuensi dari ini semua akan mendorong dan menggerakkan kehidupan yang stagnan, beku, dan terbenar dalam lumpur (kegelapan) yang hina. Dimensi manusia yang lain, yakni dimensi spiritualnya (ruhNya) akan mendorong manusia naik ke puncak spiritualnya yang tertinggi, yaitu kepada zat yang Maha Suci (Tuhan). Manusia dapat menggapai kesempurnaan spiritualitas, jika potensi

${ }^{25}$ Muhammad Yunus \& Rahmatia Yunus, Rekonsiliasi Manusia Ekonomi; Tuma'ninah vs Self Interest, (Jakarta: Feliz Book, 2013), Hal. 14. (Jakarta: Feliz Book, 2013), 14.

26 Suwito NS, Transformasi Sosial; Kajian Epistemologis Ali Syari'ati Tentang Pemikiran Islam Modern (Yogyakarta: Unggun Religi, 2004), 22.

${ }^{27}$ Supriyadi, Filsafat Sejarah, 82.

28 Yunus, Rekonsiliasi Manusia Ekonomi; Tuma'ninah vs Self Interest, (Jakarta: Feliz Book, 2013), Hal. 14., 15.

274 | Mumtäz Vol. 3 No. 1, Tahun 2019 
spiritual tersebut diberdayakan. Hal ini dapat dilakukan sejak awal manusia memiliki potensi yang berawal dari penciptaannya sendiri. ${ }^{29}$

Manusia adalah medan dimana semua energi dan sifat entitas bertemu dan melakukan tarik menarik, baik entitas ketuhanan dan entitas kesetanan. Dengan sifat yang bertentangan dan berlawanan tersebut, pada hakikatnya manusia memungkinkan untuk memiliki kebebasan memilih satu diantara dua kutub, yaitu diantara yang hina atau yang suci. Tarik menarik ini tentu akan menghasilkan suatu kecenderungan. Dan kecenderungan yang akan menetukan nasib manusia. Sehingga manusia memerlukan petunjuk-petunjuk profetik untuk sampai pada pilihan yang tepat. Nilai-nilai profetik itu mengarahkan manusia mengenal dirinya dalam menjawab pertanyaan fundamental; dari mana, untuk apa, dan akan kemana manusia pergi? Dengan demikian manusia dapat menyimpulkan tugas kemanusiaanya sebagai seorang hamba dan khalifah.

\section{Turunnya Adam ke Bumi}

Sebab utama Adam turun ke bumi bukan karena termakannya "buah khuldi" oleh Adam. Tetapi, pada dasarnya Adam memang diciptakan untuk menggarap, memakmurkan, serta membina bumi dengan baik sebagai tanggungjawab kemanusiaannya. Karena yang tahu tentang tanah adalah Adam yang memiliki unsur tanah. Dalam padangan para sufi, bahwa manusia adalah mikrokosmos, sementara alam adalah makrokosmos. Menurut Mulyadhi Kartanegara, dari ungkapan yang demikian dapat disimpulkan bahwa antara manusia dan alam memiliki hubungan yang sangat erat, diantara keduanya seakan-akan yang satu hendak mewakili dan menjelaskan yang lain. ${ }^{30}$

Ikhwan al-Shafa' menyebut alam sebagai manusia besar dan berkesimpulan bahwa manusia dan alam memiliki unsur kehidupan. ${ }^{31}$ Dalam mengola kehidupan dibutuhkan manusia yang satu frekuensi dengan alam itu sendiri. Dengan keselasaran yang dimiliki masing-masing entitas alam dan manusia, mereka dapat menciptkan suatu kolaborasi untuk membentuk peradaban manusia. Keduanya bisa membangun hubungan yang saling menguntungkan dan tidak eksploitatif. Saling memahami, menjaga, menjamin, serta mengayomi satu sama lain.

Apalagi Adam mengemban tugas sebagai seorang nabi yang secara otomatis dituntun dan diarahkan oleh Allah (QS. Al-Baqarah [2]: 37). Dengan petunjuk-petunjuk Allah tersebut Nabi Adam dijanjikan kemudahan, dengan syarat bahwa petunjuk itu diterima dan diamalkan dengan baik (QS. Al-Baqarah [2]: 38). Akan tetapi, Adam harus berusaha sekuat tenaga untuk membentuk kepribadiannya dalam rangka menjemput kebahagiaan, kemudahan, serta pertolongan Allah tersebut (QS. Ar-Ra'd [13]: 11). Usaha pertama yang dilakukan Adam adalah menyadari kesalahannya dan menyesali perbuatannya, dengan demikian turunlah kalimat dari Allah untuk meminta pengampunan.

Ajaran yang didapatkan Nabi Adam pertama kali adalah konsepsi ketauhidan yaitu memahami eksistensi Allah sebagai zat yang agung. Allah dapat memuliakan suatu mahluk dan secara bersamaan dapat pula merendahkan suatu mahluk. Allah adalah satu-satunya sumber petunjuk dan kebagiaan. Manusia tidak memiliki kewenangan apapun terhadap dirinya sendiri. Dan, beratubat adalah proses pembersihan diri, tidak hanya sekedar karena telah melakukan kesalahan, tetapi juga untuk mengihindarkan diri dari sifat tamak, sombong, iri, dan dengki yang dimiliki Iblis ataupun yang terkandung dalam diri manusia sebagai salah satu entitas.

${ }^{29}$ NS, Transformasi Sosial; Kajian Epistemologis Ali Syari'ati Tentang Pemikiran Islam Modern, 141-

30 Mulyadhi Kartanegara, Lentera Kehidupan; Panduan Memahami Tuhan, Alam, Dan Manusia (Bandung: Mizan, 2017), 149.

${ }^{31}$ Kartanegara, 152. 
Adam adalah peletak pertama peradaban profetik. Sejarahnya cukup panjang dan akan terulang secara terus menerus dalam proses kehidupan manusia. Baik kehidupan atas nama kemuliaan atau proses kehidupan yang berupa kejatuhan moral. Pilihannya ada dua, tetap membangkan serta bergelimang dosa atau memilih untuk menyadari diri atas segala kelemahan, serta meminta ampun, petunjuk, dan rahmat dari Allah sebagai zat tertinggi. Dua pilihan ini penting untuk manusia, sehingga manusia dapat bergerak membangun peradaban atau justru melenyapkan peradaban manusia. Menurut Malik Bennabi, sebagaimana dikutip Usman Syihab, bahwa akar nilai profetik adalah unsur-unsur yang membentuk kepribadian manusia dan memperkaya manusia dengan kekuatan-kekuatan yang dinamik, serta dapat menghantarkan manusia kearah peradaban. ${ }^{32}$

Dalam Al-Qur'an selalu diceritakan keadaan suatu kaum yang menentang nilai-nilai profetik yang dibawa para nabi akan mengalami kehancuran, misalnya kaum 'Ad, kaum Luth, dan Tsamud. Karena nilai-nilai profetik merupakan fondasi pembangunan peradaban para nabi. Malik Bennabi mengutarakan bahwa peradaban dibangun dengan fondasi-fondasi profetik. Hal ini didukung oleh realitas historis, bahwa nabi tidak akan diutus kecuali peradaban manusia telah mengalami kehancuran; Tauhid diselewengkan, hukum-hukum Tuhan telah dilupakan, dan moralitas masyarakatnya rendah. Karena nabi diutus untuk memperbaiki perdaban manusia baik ajaran keagaman maupun moralitas masyarkatnya. Serta mengucikan lahir dan bathin masyarakatnya, serta mengajarkan kitab-kitab dan hikmah (QS. Al-Baqarah [2]: 151).

Jika ditelusuri dalam sejarah, bahwa peradaban manusia pasti mengalami fase kemajuan, kemunduran, dan kehancuran. Menurut Ibnu Khaldun, setiap peradaban memiliki tiga generasi. Pertama, generasi yang hidup dalam keadaan primitif yang keras dan jauh dari kemewahan dan kehidupan kota, masih tinggal di pedesaan dan padang pasir. Kedua, berhasil mendirikan peradaban sehingga generasi ini beralih dari kehidupan primitif ke kehidupan kota yang penuh kemewahan. Ketiga, generasi yang menghancurkan peradaban, sebab generasi ini tenggelam dalam kemewahan, penakut dan kehilangan makna kehormatan, keperwiraan dan keberanian. $^{33}$

Jika dikaitkan dengan sejarah Adam dan keturunannya; Adam adalah generasi pertama yaitu generasi primitif yang hidupnya berpindah-pindah (nomaden) dalam mencari sumber kehidupan. Menurut Harari, generasi pertama ini disebut sebagai komplotan pemburu pengumpul. ${ }^{34}$ Sementara kehidupan Qabil dan Habil disebut sebagai generasi kedua adalah generasi yang sudah mulai mengenal pertanian dan peternakan. Hal ini dibuktikan dengan perintah kurban untuk mereka berdua (QS. Al-Maidah [5]: 27-32). Sejarah Qabil dan Habil pun bisa digolongkan sebagai generasi ketika yaitu generasi yang menghancurkan peradaban. Karena pertumpahan darah, serta perang saudara terjadi pertama kali pada masa ini. Semua terjadi akibat keserakahan, iri, dengki, dan tidak bisa menerima ketetapan Tuhan sebagai petunjuk profetik untuk nabi Adam dan keturunannya.

\section{KESIMPULAN}

Nabi Adam adalah mahluk kontroversial sejak penciptaannya. Keberadaannya mengundang perdebatan panjang, mulai dari penciptannya, realitas kesejarahannya, bahkan surganya dimana dia ditempatkan pertama kali. Disamping itu sejarah Adam harus dibaca dalam kerangka yang filosofis, karena sejarahnya memiliki makna mendalam bagi proses

\footnotetext{
${ }^{32}$ Usman Syihab, Membangun Peradaban Dengan Agama (Jakarta: Dian Rakyat, 2010), 59-60.

${ }^{33}$ Syihab, 60.

${ }^{34}$ Yuval Noah Harari, Sapiens; Riwayat Singkat Umat Manusia (Jakarta: KPG, 2017), 48-55. 
sejarah kehidupan manusia selanjutnya. Sebagaimana pepatah menyebutkan, bahwa sejarah itu mengulang dirinya sendiri.

Di dalam kisah Adam terdapat rangkaian kemungkinan bahkan kepastian bagi hidup manusia. kemungkinan bagi manusia misalnya, manusia bisa saja berada pada posisi yang mulia, hingga semua mahluk tunduk padanya. Dan bisa jadi manusia mengalami kejatuhan moral, harga diri, dan lain sebagainya, karena diakibatkan perilakunya. Sementara kepastian bagi manusia adalah bahwa manusia memiliki musuh sejati bernama Iblis dan mereka memiliki kemampuan melihat cela dan kelemahan manusia, serta kematian (ketiadaan). Dalam menjalankan kehidupan yang rumit manusia mesti berjuang mendapatkan bimbingan Tuhan, serta melaksanakan ajaran-ajaran profetik yang dibawa dan diwariskan para nabi dan rasul.

Kisah Adam adalah siklus kehidupan dalam sejarah peradaban manusia sampai akhir zaman. Manusia mesti berkaca pada kisah kehidupan Adam, bahwa kemuliaan manusia terdapat pada pengetahuan dan ketaatannya pada perintah Tuhan. Sementara kejatuhan manusia adalah ketika melupakan ajaran-ajaran Tuhan dan rendahnya moralitasnya. Sebagaimana yang disebut oleh Ibnu Khaldun, setiap peradaban memiliki pola dan siklus yang sama, yaitu; merintis, membangun, kemunduran, kehancuran. 


\section{DAFTAR PUSTAKA}

Abidin, Zainal. Filsafat Manusia; Memahami Manusia Melalui Filsafat, (Bandung: Remaja Rosdakarya, 2014), Hal. 114. Bandung: Remaja Rosdakarya, 2014.

Ahmad, Mirza Tahir. Wahyu; Rasionalitas Pengetahuan Dan Kebenaran. Jakarta: Naratja Press, 2014.

Al-Qurthubi. Tafsir Al-Qurthubi. Jakarta: Pustaka Azzam, 2007.

Ath-Thabari, Abu Ja'far Muhammad bin Jarir. Tafsir Ath-Thabari. Jakarta: Pustaka Azzam, 2007.

Audah, Ali. Nama Dan Kata Dalam Al-Qur'an: Pembahasan Dan Perbandingan. Jakarta: Pustaka Litera Antar Nusa, 2011.

Diamond, Jared. Guns, Germs, Dan Steel. Jakarta: kpg, 2013.

Fazlurrahman. Tema-Tema Pokok Dalam Al-Qur'an. Bandung: Mizan, 2017.

Hamka. Tafsir Al-Azhar. Jakarta: Citra Serumpun Padi, 2005.

Harari, Yuval Noah. Sapiens; Riwayat Singkat Umat Manusia. Jakarta: KPG, 2017.

Imani, Allamah Kamal Faqih. Tafsir Nurul Qur'an. Jakarta: Al-Huda, 2003.

Iqbal. Rekonstruksi Pemikiran Religius Dalam Islam. Bandung: Mizan, 2016.

Kartanegara, Mulyadhi. Lentera Kehidupan; Panduan Memahami Tuhan, Alam, Dan Manusia. Bandung: Mizan, 2017.

Kemenag. Tafsir Tematik Al-Qur'an; Kenabian Dalam Al-Qur'an. Jakarta: Lajnah Pentashih Al-Qur'an, 2012.

Miftahulloh. Pendidikan Profetik Perspektif Moh. Roqib Dan Implikasi Dalam Rekonstruksi Pendidikan Islam Integratif. Purwokerto: IAIN Purwokerto, 2017.

Muhammad Ali Ash-Shabuni. Shafwatut Tafasir. Jakarta: Pustaka Al-Kautsar, 2011.

Munawar-Rachman, Budhy. Ensiklopedi Nurcholis Madjid. Jakarta: Paramadina, 2011.

Nasution, Harun. Filsafat Dan Mistisme Islam. Jakarta: Bulan Bintang, 2010.

NS, Suwito. Transformasi Sosial; Kajian Epistemologis Ali Syari'ati Tentang Pemikiran Islam Modern. Yogyakarta: Unggun Religi, 2004.

Pidley, Matt. Genom; Kisah Spesies Manusia Dalam 23 Bab. Jakarta: Gramedia Pustaka Utama, 2005.

Shihab, M. Quraish. Tafsir Al-Misbah; Pesan, Kesan, Dan Keserasian Al-Qur'an. Jakarta: Lentera Hati, 2002.

Shofan, Moh. Pendidikan Paradigma Profetik; Upaya Konstruktif Membongkar Dikotomi 
Sistem Pendidikan Islam. Yogyakarta: IRCiSoD, 2004.

Supriyadi, Muflih Abdullah \& Dedi. Filsafat Sejarah. Bandung: Pustaka Setia, 2012.

Syihab, Usman. Membangun Peradaban Dengan Agama. Jakarta: Dian Rakyat, 2010.

Yunus, Muhammad Yunus \& Rahmatia. Rekonsiliasi Manusia Ekonomi; Tuma'ninah vs Self Interest, (Jakarta: Feliz Book, 2013), Hal. 14. Jakarta: Feliz Book, 2013. 